\title{
17. $\mathrm{O}^{18}$ AND $\mathrm{C}^{13}$ ISOTOPES IN LEG 44 CARBONATES: A COMPARISON WITH THE ALPINE SERIES
}

\author{
René Létolle, ${ }^{1}$ Maurice Renard, ${ }^{2}$ Maurice Bourbon, ${ }^{3}$ and Annick Filly ${ }^{4}$
}

\begin{abstract}
In this paper we present data from isotopic analyses on bulk carbonates taken from Holes 390, 390A, 391C, and 392A of DSDP Leg 44. Interpretation of the isotopic data gives clues to recrystallization processes in sediments which have been recrystallized. Bulk carbonate data gives clues to depositional environments in samples which have not been recrystallized (nannofossil oozes). The conclusions obtained from bulk carbonate data are not as precise as those obtained from isotope studies on individual fossils which are very rare in all samples at hand.

Most samples from Holes 390, 390A, and 392A are nannofossil oozes from the Blake Plateau; no samples of the fenestral limestone were taken. We studied samples from most of the stratigraphic sequence of Hole $391 \mathrm{C}$.
\end{abstract}

\section{HOLE 392A}

The isotopic data obtained from nannofossil ooze of Hole 392A give values which correspond to recrystallized carbonates, or to those subjected to early diagenesis in warm, aerated shallow water with little biogenic $\mathrm{CO}_{2}$. Although samples were taken at widely spaced intervals, thus precluding great precision, the differences in $\delta \mathrm{O}^{18}$ contents between Samples 3-2, $105 \mathrm{~cm}$ and 3-1, $102 \mathrm{~cm}$ appear to reflect changes in depositional environment: hotter waters during the middle Albian, then return to cooler conditions similar to those which prevailed in the earlier Aptian during the Campanian.

Figure 1 and Table 1 show the carbon and oxygen isotope data for Hole 392A.

\section{HOLE 390}

The trends in isotope values from Aptian-Albian sediments from Hole 390 are similar to those from Hole 392A. The same reduction in values occurs at the same stratigraphic level in the two holes which are some $20 \mathrm{~km}$ apart. This provides additional evidence that the change occurred in the depositional environment.

Figure 1 and Table 2 show the isotope data for Hole 390A.

An anomaly in the strontium content at the Maestrichtian/Danian contact (Renard and Létolle, this volume) does not correspond to any significant feature in the $\mathrm{O}^{18}$ content.

The progressive change in isotope values seen in the Barremian samples may be a result of secondary recrystallization in a marine environment.

'Laboratoire de Géologie Dynamique, Université Pierre et Marie Curie, Paris, France.

${ }^{2}$ Laboratoire de Geologie des Bassins sedimentaires, Université Pierre et Marie Curie, Paris, France.

${ }^{3}$ Ecole des Mines, Paris, France.
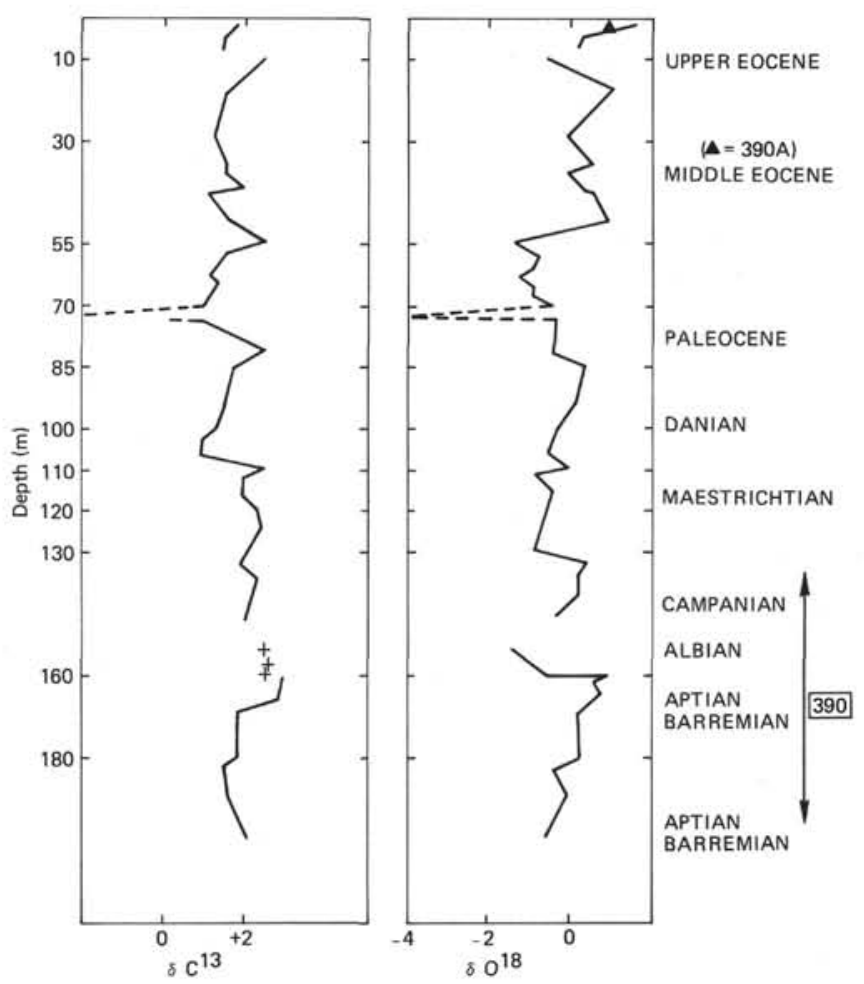

Figure 1. $\delta C^{13}$ and $\delta O^{18}$ data, Holes 390 and $390 A$.

\section{HOLE 390A}

We analyzed a large set of samples from middle Eocene to Campanian sediments. All samples are nannofossil ooze with varying amounts of siliceous material (radiolarians and some diatoms) and other debris. Our data do not show any isotopic discontinuity at the Tertiary/Cretaceous boundary.

The continuity of the oxygen isotope log (Figure 1) is broken twice. The first break occurs in the Maestrichtian sequence between Samples 13-3, $80 \mathrm{~cm}$ and 13-1, $117 \mathrm{~cm}$, 
TABLE 1

Isotope Data for Hole 392A Carbonate Samples

\begin{tabular}{cclccl}
\hline Depth $(\mathrm{m})$ & $\begin{array}{c}\text { Sample } \\
\text { (Interval in } \mathrm{cm})\end{array}$ & \multicolumn{1}{c}{ Stage } & $\delta \mathrm{C}^{13}$ & $\delta \mathrm{O}^{18}$ & Observations \\
\hline 53 & $1-1,124-126$ & Upper Campanian & +2.33 & -0.15 & Nanno-fossil ooze \\
55 & $1-2,144-145$ & & +2.10 & -0.11 & Marly nannofossil \\
& & & & & ooze \\
60.5 & $2-1,49-50$ & Middle Albian & +2.22 & -1.42 & Nannofossil ooze \\
65 & $2-2,19-20$ & & +1.84 & -1.85 & Nannofossil ooze \\
80 & $3-1,102-104$ & Aptian & +1.79 & -1.45 & Nannofossil ooze \\
84 & $3-2,105-106$ & & +2.88 & +0.68 & Nannofossil ooze \\
87 & $3-3,70-71$ & \multirow{2}{*}{ Barremian } & +3.58 & +0.99 & Nannofossil ooze \\
97 & $4-1,125-126$ & +2.54 & +0.11 & Nannofossil ooze \\
\hline
\end{tabular}

TABLE 2

Isotope Data for Hole 390 Carbonate Samples

\begin{tabular}{cccccl}
\hline $\begin{array}{c}\text { Depth } \\
(\mathrm{m})\end{array}$ & $\begin{array}{c}\text { Sample } \\
\text { (Interval in cm) }\end{array}$ & Series/Stage & $\delta \mathrm{C}^{13}$ & $\delta \mathrm{O}^{18}$ & Observations \\
\hline \multirow{4}{*}{10} & $1-1,135-136$ & Middle Eocene & +1.74 & +1.60 & $\begin{array}{l}\text { Nannofossil } \\
\text { ooze }\end{array}$ \\
& $1-3,86-87$ & & +1.50 & +0.25 & \\
140 & $3-1,112-114$ & Albian & +1.40 & +0.20 & \\
& & & +2.35 & -1.50 & Nannofossil \\
& $3-3,129-131$ & & +2.40 & -1.25 & \\
& $3-3,147-149$ & & +2.40 & -0.05 & \\
160 & $5-1,133-134$ & Aptian & +2.85 & +0.60 & \\
& $5-2,138-140$ & & +2.86 & +0.73 & \\
& $6-1,126-128$ & Barremian & +1.85 & +0.09 & Limestone with \\
& & & & & benthic fauna \\
& $8-2,51-53$ & & +1.75 & +0.20 & \\
$8-4,131-133$ & & +1.42 & -0.45 & \\
$8-6,142-144$ & & +1.60 & -0.12 & \\
$9-1,70-80$ & & +2.15 & +0.06 & \\
\hline
\end{tabular}

and corresponds to a color change from brown to bluish gray (change in redox). The carbon isotope composition, however, does not change at this level. The rise of $\delta \mathrm{O}^{18}$ could possibly be attributed to a progressively lower temperature from Barremian to Albian time followed by an abrupt return to warmer climates. But we can perhaps better interpret it as reflecting a slight diagenetic lowering of the $\mathrm{O}^{18}$ content (from about $+1^{0}$ to $-2 \%$ for the most deeply buried samples). The constant decrease in the strontium content (Renard and Létolle, this volume) favors such an interpretation. The distinct reduction of the $\delta \mathrm{C}^{13}$ at level $10-6,90 \mathrm{~cm}$ appears to result from the introduction of organic carbon during the synthesis of carbonate. This corresponds to the appearance of benthic foraminifers and is accompanied by a very low manganese content (Renard and Létolle, this volume).

The gradual increase in $\mathrm{O}^{18}$ from Sample 11-6, $21 \mathrm{~cm}$ (Danian) to Core 8, Section 4 (Paleocene) surely reflects cooler water temperatures followed by renewed warming up to the early Eocene (Sample 4-6, $106 \mathrm{~cm}$ ). Here too benthic foraminifers occur, and introduction of organic carbon could have caused the simultaneous decrease of the $\delta \mathrm{C}^{13}$. One may imagine that the water became shallower and warmer which could result in the lower $\mathrm{O}^{18}$ values.

In overlying sediments, the oxygen values are definitely positive versus the Pee Dee Belemnite scale (PDB) and certainly reflect cooler temperatures following the warmer Paleocene climate. (The data from Eocene samples from Hole 390 complements those from Hole 390A.) See Table 3 for carbon and oxygen isotope data.

\section{HOLE 391C}

The petrology of Jurassic to Lower Cretaceous sediments, from which most of our samples came, is discussed in a companion paper (Bourbon, this volume). Table 4 shows the carbon and oxygen isotope data for Hole 391C.

Note that the $\delta \mathrm{O}^{18}$, except for some samples found either at the lower part of the core (Tithonian) or just under the black shales, is much lower than in Holes 390 and 392 (Figure 2). Petrology and geochemical calculations (i.e., the "paleotemperature equation") shows this is neither the result of introduction of isotopes from continental (meteoric) waters, nor attributable to very high temperatures during deposition.

The highest values, around $-2 \%$ for the Tithonian, and $-1 \%$ versus the PDB for the Aptian, probably indicate the original isotope conditions. In this case, when deposition of the black shale began, the temperature must have been lower than during Tithonian time. All the other values reflect diagenesis and isotope exchange. Stylolitization and replacement of radiolarians by calcispheres give further evidence for such a process, as does the gross inverse correlation between $\delta \mathrm{O}^{18}$ and carbonate content, noted in Leg 11 samples by Brennecke (1977), who discussed it thoroughly following the reasoning given below.

Consider the isotope exchange of carbonate with interstitial water during diagenesis. As the porosity of the sediment is not very high, the quantity of oxygen present in the carbonate is much greater than that in the water. In order for the carbonate to "lose" such a quantity of $\mathrm{O}^{18}$ (as indicated by the low $\delta \mathrm{O}^{18}$ values), the system must have been open; that is, a flux of water was necessary to have carried away the excess isotopes. The highest observed $\mathrm{O}^{18}$ values are found in the most clayey samples, or in samples interbedded with clays or marls. This suggests that the system may have been "almost closed," as opposed to conditions in thick limestones in which water can more easily circulate.

Also consider that an isotopic change in carbonate oxygen during recrystallization is linked to the temperature and the isotope content of the interstitial water. When a carbonate particle is formed in equilibrium fractionation $(\epsilon)$ occurs and $\epsilon \approx \delta$ carbonate $-\delta$ water, ${ }^{4}$ which is a function of the temperature. A carbonate with a $\delta$ of $-1 \%$ versus PDB is in equilibrium with seawater ( $\delta=0 \%$ vs SMOW) at approximately $+21^{\circ} \mathrm{C}$, when a carbonate with $\delta=-4 \%$ ooversus PDB would correspond in the same conditions to about $+34^{\circ} \mathrm{C}$.

Carbonate will re-equilibrate if it comes into contact with water of a different isotopic composition, and/or at a different temperature from that where it was originally precipitated. We may search, then, for the recrystallization conditions of carbonate with an initial $\delta$ of $-1 \%$ versus PDB.

The isotope balance between a certain quantity of oxygen in carbonate (C) and in water (W) is written, with $\delta_{\mathrm{ci}}$ and $\delta_{\mathrm{wi}}$ as initial isotope values and $\delta_{\mathrm{cf}}$ and $\delta_{\mathrm{wf}}$ as final carbonate and water values, provided that $\mathrm{C}$ and $\mathrm{W}$ do not change:

\footnotetext{
${ }^{4}$ The $\mathrm{O}^{18}$ of carbonate and water are expressed on the same scale which is the Standard Mean Ocean Water scale; values on the PDB scales are approximately $310 / 00$ higher than in the SMOW scale; PDB scale is traditional in carbonate oxygen isotope measurements.
} 
TABLE 3

Isotope Data for Hole 390A Carbonate Samples

\begin{tabular}{|c|c|c|c|c|c|}
\hline $\begin{array}{l}\text { Depth } \\
\text { (m) }\end{array}$ & $\begin{array}{c}\text { Sample } \\
\text { (Interval in } \mathrm{cm} \text { ) }\end{array}$ & Series/Stage & $\delta \mathrm{C}^{13}$ & $\delta \mathrm{O}^{18}$ & Observations \\
\hline & $1-1,94-96$ & Middle Eocene & +1.52 & +0.96 & Nannofossil ooze \\
\hline & $2-2,46-48$ & & +1.27 & -0.10 & $\begin{array}{l}\text { Nannofossil ooze + rad + } \\
\text { zeolites + glass }\end{array}$ \\
\hline \multirow[t]{3}{*}{31} & $3-2,72-73$ & & +1.52 & +0.56 & Siliceous nannofossil \\
\hline & $3-4,109-110$ & & +1.44 & -0.06 & ooze + rads + \\
\hline & $4-1,95-96$ & Lower Eocene & +1.73 & +0.27 & diatoms \\
\hline \multirow[t]{27}{*}{45} & $4-5,86-87$ & & +1.12 & +0.45 & Nannofossil chalk \\
\hline & $4-6,106-107$ & & +1.51 & +0.80 & Nannofossil chalk \\
\hline & $5-1,70-72$ & & +1.17 & -0.75 & Nannofossil chalk + silica \\
\hline & $5-2,135-136$ & & +1.47 & -0.87 & Nannofossil chalk + silica \\
\hline & $6-1,26-28$ & & +1.24 & -0.98 & Nannofossil chalk + silica \\
\hline & $6-3,90-91$ & & +1.13 & -1.13 & Nannofossil chalk + silica \\
\hline & $6-5,89-91$ & & +1.26 & -0.97 & Nannofossil ooze \\
\hline & $6-6,89-90$ & & +1.19 & -0.91 & Sil. nannofossil ooze \\
\hline & $7-1,131-133$ & & +0.93 & -0.58 & Sil. nannofossil ooze + dol.? \\
\hline & $7-2,78-79$ & & -2.23 & $-7.53(?)$ & Sil. nannofossil ooze + dol.? \\
\hline & $7-4,138-140$ & & +0.93 & -0.32 & Sil. nannofossil ooze + dol.? \\
\hline & $8-2,34-36$ & Upper Paleocene & +2.45 & -0.41 & Nannofossil ooze \\
\hline & $8-4,126-128$ & & +1.63 & +0.25 & \\
\hline & $9-1,30-35$ & Danian & +1.41 & +0.12 & \\
\hline & $10-1,84-86$ & & +1.31 & -0.35 & \\
\hline & $10-3,80-82$ & & +0.98 & -0.51 & \\
\hline & $10-6,90-92$ & & +0.95 & -0.62 & \\
\hline & $11-4,100-102$ & & +2.34 & -0.11 & \\
\hline & $11-6,21-23$ & & +1.95 & -0.92 & \\
\hline & $12-1,48-50$ & Maestrichtian & +1.90 & -0.55 & \\
\hline & $12-3,70-72$ & & +2.15 & -0.62 & Marly \\
\hline & $12-6,31-33$ & & +2.34 & -0.75 & \\
\hline & $13-1,117-119$ & & +2.10 & -0.95 & \\
\hline & $13-3,80-86$ & & +1.93 & +0.31 & High carbonate \\
\hline & $14-1,139-140$ & & +2.15 & +0.15 & \\
\hline & $14-3,80-82$ & Campanian (?) & +2.04 & -0.05 & \\
\hline & $14-5,82-83$ & & +1.95 & -0.35 & \\
\hline
\end{tabular}

$$
\mathrm{C} \delta_{\mathrm{ci}}+\mathrm{W} \delta_{\mathrm{wi}}=\mathrm{C} \delta_{\mathrm{cf}}+\mathrm{W} \delta_{\mathrm{wf}}
$$

$\epsilon$ is the apparent fractionation at $\mathrm{t}^{\circ} \mathrm{C}$.

$$
\text { Taking } \mathrm{x}={ }_{\mathrm{C}}^{\mathrm{W}} \text { gives: } \delta_{\mathrm{ci}}+\mathrm{x} \delta_{\mathrm{wi}}=\delta_{\mathrm{cf}}+\mathrm{x}\left(\delta_{\mathrm{cf}}-\epsilon\right) \text {. }
$$

In our case we know the values for $\delta_{\text {ci }}$ and $\delta_{\text {cf }}$ (about $+29 \%$ and $+26 \%$ vs SMOW, respectively) so we can determine an approximate relationship for $\delta$ and t, by applying the paleotemperature equation given by Craig (1965):

$$
\epsilon \cong 34-0.23 \mathrm{t}
$$

where $\mathrm{x} \delta_{\mathrm{wi}}=(0.23 \mathrm{t}-8) \mathrm{x}-3$.

Three factors must be considered: $\mathrm{t}, \delta_{\mathrm{wi}}$ and $\mathrm{x}$ (proportion of oxygen atoms reacting in the water and in carbonate). Two possibilities exist for $\delta$ wi.

1) $\delta_{\text {wi }}$ equals, or is close to zero. That is, it corresponds to present seawater, even if we assume a slightly different value for seawater (i.e., Craig, 1965).

2) $\delta_{\text {wi }}$ is lower than SMOW.

The temperature is at least equal to $0^{\circ} \mathrm{C}$ (the minimum temperature could have been higher if bottom temperatures were higher in the secondary era, which has not been proven).
The value of $x$ is necessarily positive; if lower than 1, the system carbonate water could be considered as closed; but as the efficient porosity may not be higher than, perhaps, 0.30 for $w$ values higher than 0.3 , the system would necessarily be open, which means a flow of interstitial water within it.

The relation between the three parameters indicates that for a set of "reasonable" values for $\delta_{\text {wi }}$ (i.e., from $+1 \%$ to $-1 \%$ ), the temperature was at least $30^{\circ} \mathrm{C}$ for $\delta_{w i}=-3^{\circ}$ to $39^{\circ} \mathrm{C}$ for $\delta_{\text {wi }}=+1$.

These give very high values for $x$ which in any case correspond to open systems. In order to get reasonable $x$ values (i.e., about 0.1 ) with the same set of $\delta_{\text {wi }}$ values, one needs excessively high temperature which is incompatible with the observed recrystallizations.

Nevertheless, if we consider the possibility that $\delta_{\text {wi }} \approx 0$, which leads to temperatures higher than $35^{\circ} \mathrm{C}$, such temperatures could be the result of:

1) a very high geothermal gradient. If the trend of oxygen isotope evolution from Section 25 to Section 45 (variation of $2 \%$ delta units for a depth of $175 \mathrm{~m}$ ), is caused by the geothermal gradient, then the gradient would be about $8^{\circ} \mathrm{C}$, which seems too high to be realistic.

2) lateral heat flux, from volcanic sources (?). This heat source cannot be presently discarded as zeolites are sometimes present and a manganese anomaly exists in the same region of the site (see Renard et al., this volume). 
TABLE 4

Isotope Data for Hole 391C Carbonate Samples

\begin{tabular}{|c|c|c|c|c|c|}
\hline $\begin{array}{c}\text { Sample } \\
\text { (Interval in } \mathrm{cm} \text { ) }\end{array}$ & $\begin{array}{l}\text { Depth } \\
\text { (m) }\end{array}$ & Stage & ${ }^{\delta} \mathrm{C}^{13}$ & ${ }^{\delta} \mathrm{O}^{18}$ & Observations \\
\hline $5-1,149-150$ & 68 & & - & & No carbonate \\
\hline $6-2,146-148$ & 69 & & -20.18 & +5.74 & \\
\hline $9-2,60-62$ & 833 & & +1.78 & -1.08 & \\
\hline $9-2,63-64$ & & & +1.89 & -1.10 & \\
\hline $10-2,39-41$ & 901 & & - & - & \\
\hline $10-2,61-63$ & & Lower Albian & +1.10 & -0.32 & \\
\hline $10-3,76-78$ & & Upper Aptian & - & - & \\
\hline $11-1,100-101$ & 924 & & $\begin{array}{c}+1.67 \\
-\end{array}$ & $\begin{array}{c}-1.72 \\
-\end{array}$ & \\
\hline $\begin{array}{l}11-1,138-140 \\
12-3,4-6\end{array}$ & 959 & Aptian & $+\overline{0.71}$ & $-\overline{3.51}$ & \\
\hline $12-6,74-75$ & & & +0.83 & -1.74 & \\
\hline $12-6,101-103$ & & & +0.99 & -1.58 & \\
\hline $14-1,89-92$ & 1000 & Upper Val., Lower Ber. & +1.66 & -2.91 & \\
\hline $14-1,92-93$ & & & +1.52 & -3.53 & \\
\hline $15-3,28-30$ & & & +1.44 & -4.46 & Calcarenite \\
\hline $16-3,56-57$ & 1025 & & +1.10 & -3.86 & \\
\hline $16-4,33-35$ & & & +0.95 & -4.66 & \\
\hline $17-1,97-98$ & & & +0.90 & -4.02 & \\
\hline $18-1,90-92$ & 1040 & & +0.83 & -4.11 & Calcospheres \\
\hline $18-1,93-94$ & & & +1.25 & -7.71 & Pyrite \\
\hline $21-4,129-132$ & & & +0.64 & -4.56 & \\
\hline $21-4,146-150$ & 1130 & & & -4.32 & \\
\hline $\begin{array}{l}24-3,123-127 \\
24-4,84-86\end{array}$ & 1130 & Upper Ber., Lower Val. ? & $\begin{array}{l}+1.61 \\
+1.87\end{array}$ & -3.98 & \\
\hline $\begin{array}{l}24-4,84-86 \\
25-3,67-72\end{array}$ & 1150 & & $\begin{array}{l}+1.87 \\
+1.92\end{array}$ & -4.14 & \\
\hline $26-2,33-35$ & & & +1.47 & -4.82 & \\
\hline $26-3,43-45$ & & & +1.23 & -5.66 & \\
\hline $26-4,103-105$ & & & +1.00 & -2.70 & \\
\hline $27-1,142-145$ & 1155 & & +2.12 & -3.87 & \\
\hline $27-4,15-18$ & & & +0.93 & -7.78 & \\
\hline $28-1,148-150$ & 1164 & & +1.96 & -3.72 & \\
\hline $29-3,141-148$ & 1176 & & +1.41 & -3.29 & \\
\hline $30-2,63-65$ & & & +0.94 & -3.79 & \\
\hline $30-3,47-50$ & & & +0.80 & -4.3 & \\
\hline $31-1,61-66$ & 1191 & & +0.78 & -4.47 & \\
\hline $32-2,85-87$ & & & +0.08 & -4.79 & \\
\hline $32-3,10-13$ & & & +0.64 & -4.07 & \\
\hline $32-4,77-79$ & & & +0.45 & -4.24 & \\
\hline $32-4,146-150$ & & & +0.59 & -4.34 & \\
\hline $33-3,108-111$ & 1214 & Berriasian & +1.41 & -3.69 & \\
\hline $34-3,56-58$ & & Lower Tithonian ? & +0.89 & -3.95 & \\
\hline $35-1,91-93$ & 1230 & Upper Berriasian ? & +0.88 & -3.96 & \\
\hline $36-1,96-99$ & & & +0.92 & -4.10 & \\
\hline $36-4,139-143$ & & & -0.93 & -3.36 & \\
\hline $37-1,111-116$ & 1250 & & +0.87 & -3.45 & \\
\hline $38-2,27-29$ & 1259 & & +1.12 & -3.47 & \\
\hline $40-2,44-48$ & 1278 & Upper Tithonian & +1.00 & -4.83 & \\
\hline $40-4,126-130$ & & & +1.06 & -2.65 & \\
\hline $41-1,86-88$ & & & +0.88 & -4.87 & \\
\hline $43-2,22-25$ & 1307 & & +0.81 & -4.85 & \\
\hline $44-6,10-12$ & & & +1.24 & -3.85 & Stylolites \\
\hline $45-2,74-77$ & 1326 & & +1.19 & -4.20 & Interbedded red and \\
\hline $45-2,78-80$ & & & +1.28 & -2.76 & green limestone \\
\hline $47-1,40-45$ & 1343 & Lower Tithonian & +1.35 & -1.90 & Hydroxides \\
\hline $47-1,63-64$ & & & +1.33 & -3.88 & Iron \\
\hline $47-1,80-85$ & & & +1.04 & -1.47 & Calc. mudstone \\
\hline $48-1,110-115$ & 1354 & & +1.32 & -2.15 & \\
\hline $50-1,35-36$ & 1371 & & +2.02 & -2.85 & Red claystone \\
\hline $50-1,125-127$ & & & +1.53 & -3.73 & \\
\hline $52-2,109-111$ & & & +1.49 & -4.22 & Claystone \\
\hline $52-4,64-65$ & & & +1.55 & -3.00 & \\
\hline $52-4,125-127$ & & & +1.30 & -0.84 & \\
\hline
\end{tabular}

An alternate possibility is that water of the recrystallization environment had a $\delta<0$. In order to get such an isotopic composition for marine water, an exchange involving previously existing material is needed. Lawrence
(1974), Lawrence et al. (1975), and Perry et al. (1976) have shown that recrystallization of low temperature, high $\delta \mathrm{O}^{18}$, silicate minerals (e.g., cherts) using primeval hightemperature, low $\delta \mathrm{O}^{18}$, volcanic material (for instance, 

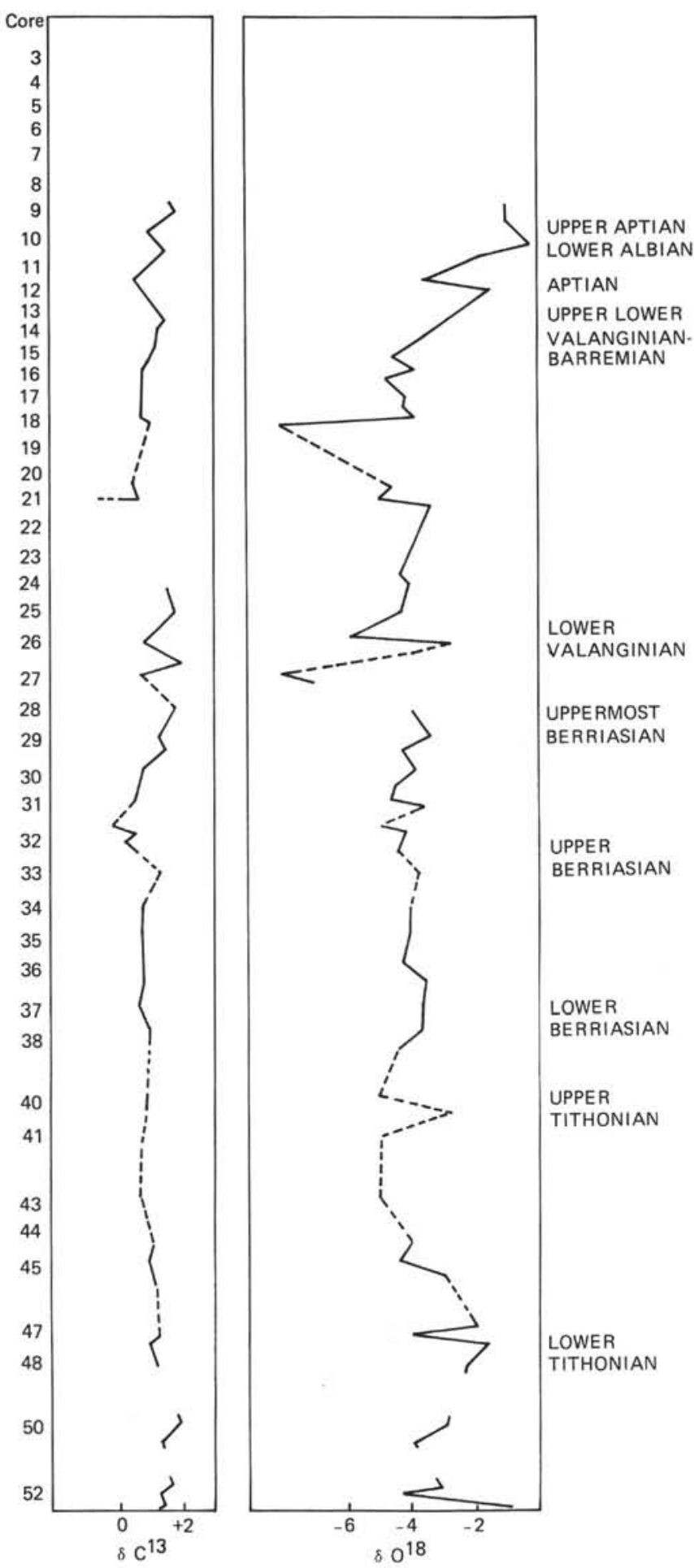

Figure 2. $\delta C^{13}$ and $\delta O^{18}$ data, Hole $391 C$.

shards of glass) may lower the water composition by several per mil through the classic "reservoir effect." There is much evidence of silica recrystallization in the Hole 391C samples, but the original material from this hole appears to have been high $\delta \mathrm{O}^{18}$ radiolarians. Consequently, the explanation given by Brennecke (1977) is harder to apply in the case of Hole 391C.
If, however, we consider the possibility of low $\delta$ interstitial water (the implication of an open system is evident), we may have recrystallization leading to the observed $\delta$ for carbonates without unusually high temperatures. For instance, with $\delta_{\mathrm{wi}}=-2 \%$ the lowest mean admissible temperature would be $26^{\circ} \mathrm{C}$. The high $\mathrm{O}^{18}$ gradient discussed above might be attributed, in part, to a normal geothermal gradient, and in part, to variations in the $\mathrm{O}^{18}$ content of exchanging water. So we may conclude that water moved through the sediment undergoing diagenesis, which is easily possible by thermal convection, and that the composition of an interstitial water does not necessarily reflect the composition of the sediment where it is taken off, but rather an integration of the chemical and isotopic conditions of the succession of layers through which it passed.

We were able to extract a small quantity of carbonate from the black shale sample (Sample 391C-6-2, $148 \mathrm{~cm}$ ) and the very low $\delta \mathrm{C}^{13}$ shows it was formed from the decarboxylation of organic matter: however, the high $\mathrm{O}^{18}$ content cannot be explained in any simple way. We must now determine why the Tithonian samples have an apparently preserved isotopic composition. Clay beds are much more common in this part of the core and the explanation invoked relative to open systems cannot easily be applied here. These samples may have recrystallized with their own water.

The $\mathrm{C}^{13}$ values are uniform but show a slight decrease in Hole 391C, upward from Section 52 to Section 30. In Section 30 they shift up again. The evolution of $\mathrm{C}^{13}$ and $\mathrm{O}^{18}$ is roughly parallel, the fractionation factor for carbonate being much smaller than for $\mathrm{O}^{18}$. In any case, the $\delta \mathrm{C}^{13}$ corresponds to carbonate formed without a great proportion of biogenic $\mathrm{CO}_{2}$ (except in the case of Section 21).

Briançonnais series: We can compare the Leg 44 sequence with a contemporaneous series of the Alps (the Soureliou Series) which has been petrologically studied by Bourbon (this volume) (Table 5 and Figure 3).

We detect some apparent concordant trends between the Soureliou Series and the Hole 391C sequence (shown schematically on Figure 4). The same slight trend of $\mathrm{C}^{13}$ and the same lowering of $\mathrm{O}^{18}$ values at approximately equivalent stratigraphic levels occurs. Moreover, Soureliou Series and cores from Hole 391C are similar petrologically. Black shales are also found in the Upper Cretaceous of the Briançonnais series. The $\mathrm{O}^{18}$ values, however, are distinctly lower in the Soureliou Series than in the Hole 391C sediments, although Brennecke (1977) has found even lower values in Leg 11 samples. The Alpine deposits were never deeply buried, as were the Hole $391 \mathrm{C}$ sediments, and apparently were not subjected to volcanic influences but have undergone the tectonic stress of alpine movement. ${ }^{5}$ So we cannot invoke the same explanation for an apparently convergent evolution of the isotopic composition of two series which are also convergent in petrology, lithology, and perhaps, paleogeography. At the present time, we only point out such convergences. Possibly the similarities in

\footnotetext{
${ }^{5}$ We have no isotopic evidence of carbonate recrystallization by meteoric water in the Soureliou Series.
} 

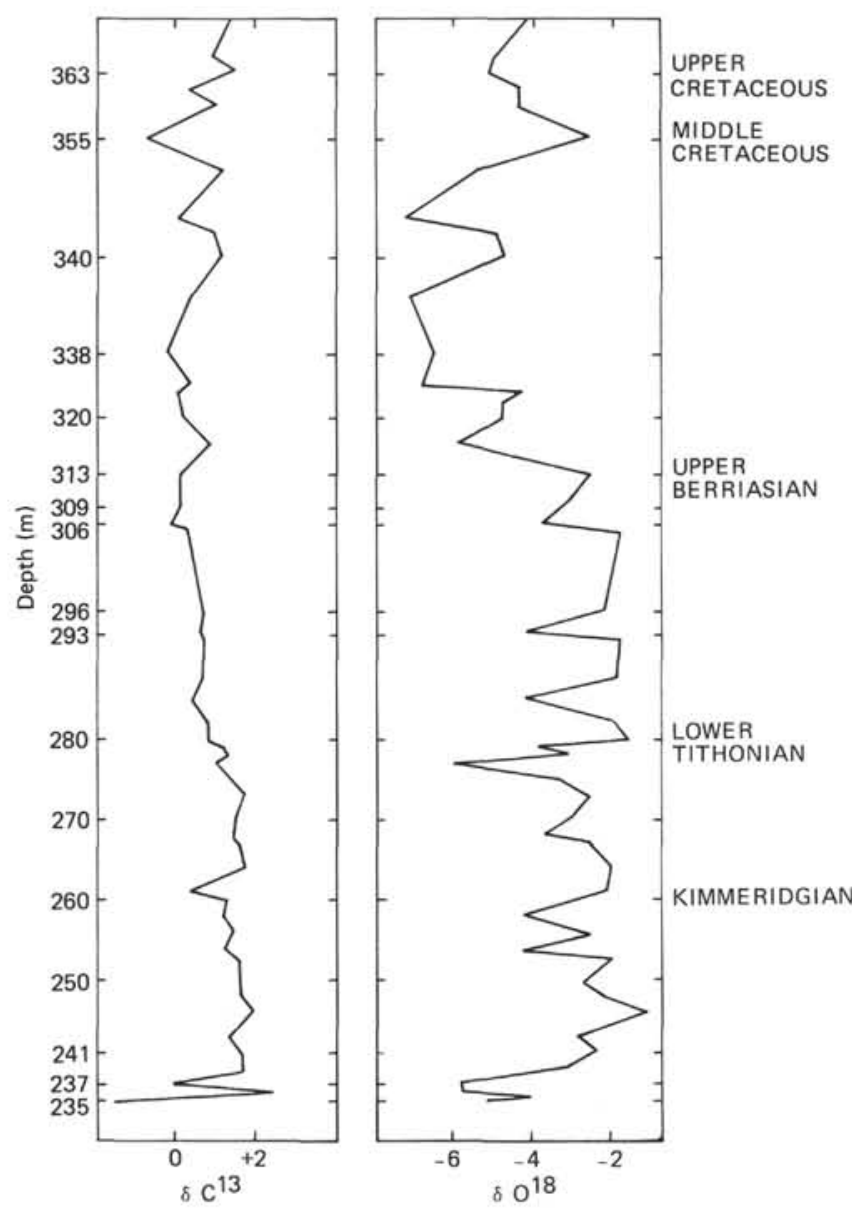

Figure 3. $\delta C^{13}$ and $\delta O^{18}$ data, Soureliou Series.

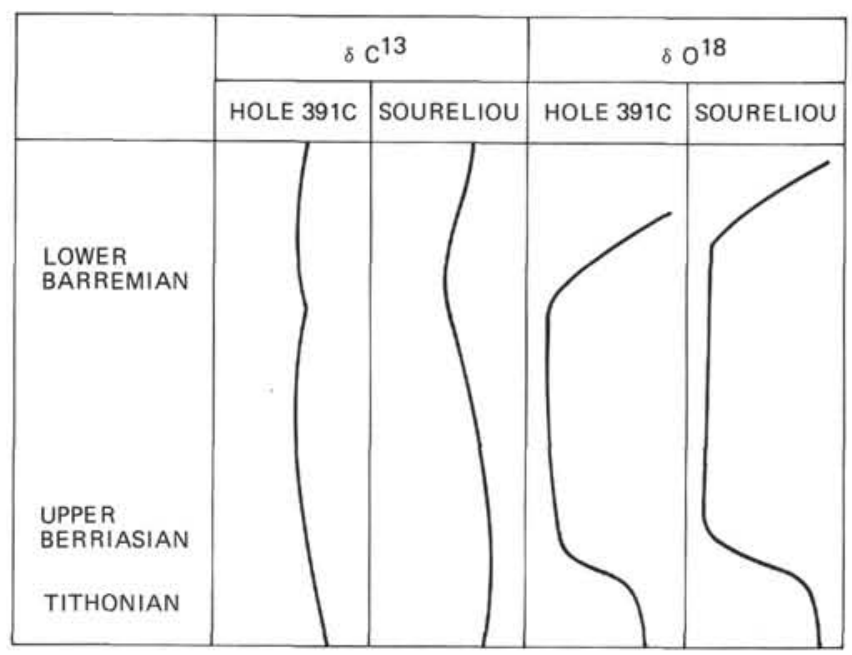

Figure 4. Comparison of $\delta C^{13}$ and $\delta O^{18}$ between Hole $391 C$ and the Soureliou Series.

petrology and depositional environment ${ }^{6}$ are themselves linked to comparable geological settings which have monitored the parallelism in carbon isotope content. The carbon isotope content seems to be little influenced by post-

${ }^{6}$ Note the similarity of radiolarian abundance in each series relative to the lowering of the oxygen isotope composition.

TABLE 5

Soureliou Series (Brianconnais, French Alps)

\begin{tabular}{|c|c|c|c|c|}
\hline $\begin{array}{l}\text { Sample } \\
\text { number }\end{array}$ & Stage & ${ }^{8} \mathrm{C}^{13}$ & ${ }^{6} \mathrm{O}^{18}$ & Observations \\
\hline 371 & Paleocene? & +1.32 & -4.04 & Calcarenites \\
\hline 365 & & +0.98 & -4.98 & \\
\hline 363 & & +1.48 & -5.13 & \\
\hline 361 & Upper Cretaceous & +0.41 & -4.48 & \\
\hline 359 & Middle Cretaceous & +1.11 & -4.35 & Radiolarian limestone \\
\hline 355 & & -0.62 & -2.64 & \\
\hline 351 & & +1.15 & -5.41 & \\
\hline 345 & Neocomian & +0.10 & -7.18 & \\
\hline 343 & & +0.96 & -4.95 & \\
\hline 340 & & +1.10 & -4.72 & \\
\hline 335 & & +0.30 & -7.05 & \\
\hline 328 & & -0.13 & -6.51 & \\
\hline 324 & & +-.23 & -6.76 & \\
\hline 323 & & +0.07 & -4.15 & \\
\hline 322 & & +0.06 & -4.77 & \\
\hline 320 & & +0.17 & -4.79 & \\
\hline 317 & & +0.90 & -5.61 & \\
\hline 313 & & +0.09 & -2.59 & \\
\hline 309 & & +0.10 & -3.37 & \\
\hline 307 & & -0.12 & -3.72 & \\
\hline 306 & & +0.30 & -1.84 & \\
\hline 296 & Upper Berriasian & +0.69 & -2.19 & \\
\hline 294 & & +0.56 & -4.06 & \\
\hline 293 & & +0.67 & -1.82 & \\
\hline $288 \mathrm{a}$ & & +0.69 & -1.87 & \\
\hline $288 \mathrm{~b}$ & & +0.67 & -2.13 & Radiolarian mud and \\
\hline 285 & & +0.42 & -4.20 & calcarenite \\
\hline 283 & & +0.81 & -2.20 & \\
\hline 280 & & +0.82 & -1.81 & \\
\hline 279 & & +1.19 & -4.00 & \\
\hline 278 & & +1.31 & -3.17 & \\
\hline 277 & Lower Portlandian & +0.99 & -6.08 & \\
\hline 275 & & +1.37 & -3.46 & \\
\hline 273 & Kimmeridgian-Portlandian & +1.70 & -2.60 & \\
\hline 270 & & +1.44 & -3.07 & Calcarenites \\
\hline 268 & & +1.40 & -3.77 & \\
\hline 267 & & +1.58 & -2.70 & \\
\hline 264 & & +1.78 & -2.05 & \\
\hline 261 & & +0.38 & -2.09 & \\
\hline 260 & & +1.24 & -2.98 & \\
\hline 258 & & +1.15 & -4.27 & \\
\hline 256 & & +1.45 & -2.67 & \\
\hline 254 & & +1.23 & -4.11 & \\
\hline 253 & & +1.55 & -2.11 & \\
\hline 250 & & +1.64 & -2.76 & \\
\hline 248 & & +1.58 & -2.37 & Radiolarian limestone \\
\hline 246 & & +1.95 & -1.23 & and calcarenites \\
\hline 243 & & +1.27 & -2.92 & \\
\hline 241 & & +1.68 & -2.48 & \\
\hline 239 & & +1.61 & -3.13 & \\
\hline 237 & & -0.01 & -5.90 & Radiolarian limestone \\
\hline $236 \mathrm{~s}$ & & +2.22 & -5.81 & \\
\hline 236 & & +1.58 & -4.20 & \\
\hline 235 & & -1.56 & -5.20 & \\
\hline
\end{tabular}

depositional transformations and the conditions which caused changes of the oxygen isotope composition.

\section{ACKNOWLEDGMENTS}

This work was performed with the assistance of Comité National d'Exploitation des Océans (France), and we discussed the manuscript with Y. Lancelot and J.C. Fontes. We heartily acknowledge all this assistance.

\section{REFERENCES}

Brennecke, J.C., 1977. A comparison of the stable oxygen and carbon isotope composition of Early Cretaceous and Late Jurassic carbonates from Sites 105 and 367. In Lancelot, Y., Seibold, E. et al., Initial Reports of the Deep Sea Drilling Project, Volume 41: Washington (U.S. Government Printing Office, p. 937-956.

Craig, H., 1965. The measurement of oxygen isotope paleotemperatures. Spoleto meeting on Stable isotopes in oceanographic studies and paleotemperatures, C.N.R., Pisa, Italia, p. 1-24. 
Lawrence, J.R., 1974. Stable oxygen and carbon isotopes variations in pore waters, carbonates and silicates, Sites 225 and 228, Red Sea. In Whitmarsh, R.B., Ross, D.A., et al., Initial Reports of the Deep Sea Drilling Project, Volume 23: Washington (U.S. Government Printing Office), p. 939942.

Lawrence, J.R., Gieskes, J.M., Broecker, W.S., 1975. Oxygen isotope and cation composition of D.S.D.P. pore waters and the alteration of layer II basalts: Earth Planet Sci. Lett., v. 27, p. 1-10.

Perry, E.A., Gieskes, J.M., and Lawrence, J.R., 1976. Mg, Ca and $\mathrm{O}^{18} \mathrm{O}^{16}$ exchange in the sediment pore water system, Hole 149, DSDP: Geochim. Cosmochim. Acta, v. 40, p. 413-423.

Savin, S.M., Douglas, R.H., and Stehli, F.G., 1975. Tertiary marine paleotemperature: Geol. Soc. Am. Bull., v. 86, p. 1499-1510. 